\title{
ANALISIS KESALAHAN SISWA DALAM MENYELESAIKAN SOAL PISA KATEGORI FORMULATE
}

\author{
Laili Fa'iq Fadhilah \\ Program Studi Pendidikan Matematika, FMIPA, Universitas Negeri Surabaya \\ e-mail: lailifadhilah18@gmail.com \\ Abdul Haris Rosyidi \\ Program Studi Pendidikan Matematika, FMIPA, Universitas Negeri Surabaya \\ e-mail: abdulharis@unesa.ac.id
}

\begin{abstract}
Abstrak
Berdasarkan hasil survey PISA sejak tahun 2000 sampai 2018 menunjukkan kemampuan literasi matematika siswa Indonesia masih rendah. Hal tersebut dikarenakan siswa Indonesia masih mengalami kesulitan dalam menyelesaikan soal PISA. Akibatnya, banyak kesalahan yang dilakukan oleh siswa ketika menyelesaikan soal PISA. Soal PISA dibagi menjadi 3 kategori proses, salah satunya yaitu Formulate. Formulate merupakan kegiatan mengubah secara bertahap masalah kontekstual yang disajikan ke dalam model matematika. Jenis penelitian ini merupakan penelitian deskriptif kualitatif yang bertujuan untuk mendeskripsikan kesalahan siswa dalam menyelesaikan soal PISA kategori formulate pada setiap konten. Subjek yang diambil yaitu siswa kelas VIII yang terdiri dari 4 siswa untuk 4 konten PISA. Pengumpulan data dilakukan dengan pemberian tes 4 soal PISA kategori formulate pada setiap konten dan wawancara. Data dianalisis berdasarkan indikator kesalahan siswa pada proses formulate. Hasil penelitian menunjukkan, pada konten perubahan dan hubungan, siswa mengalami kesalahan dalam memahami soal yaitu salah menafsirkan pertanyaan, mentransformasi soal yaitu salah dalam menuliskan prosedur penyelesaian, dan keterampilan proses yaitu salah dalam proses perhitungan. Pada konten ruang dan bentuk, siswa mengalami kesalahan dalam memahami soal yaitu tidak lengkap tidak lengkap menyebutkan informasi untuk menyelesaikan soal dan keterampilan proses yaitu salah dalam memilih rumus. Pada konten bilangan, siswa mengalami kesalahan dalam memahami soal yaitu salah menafsirkan informasi pada soal, mentransformasi soal yaitu salah dalam mengubah kalimat yang ada pada soal menjadi bentuk matematis, dan keterampilan proses yaitu salah dalam proses perhitungan. Pada konten ketidakpastian dan data, siswa mengalami kesalahan dalam membaca soal yaitu salah dalam membaca kata penting pada soal, mentransformasi soal yaitu tidak lengkap dalam menuliskan prosedur penyelesaian, dan keterampilan proses yaitu salah dalam memilih rumus yang akan digunakan untuk menyelesaikan soal.
\end{abstract}

Kata Kunci: analisis kesalahan, formulate, Soal PISA.

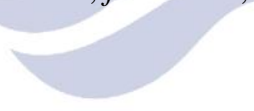

\section{Abstract}

Based on the results of the PISA survey from 2000 to 2018, the mathematical literacy ability of Indonesian students is still low. That is because Indonesian students are still having trouble solving PISA questions. Correcting, many mistakes made by students to solve PISA questions. The PISA question is divided into 3 process categories, one of which is Formulate. Formulate is the activity of gradually changing the contextual problems presented into a mathematical model. The type of this research is descriptive qualitative study that aims to describe the mistakes of students in solving PISA questions in the formulate category on each content. Subjects taken were students of class VIII consisting of 4 students for 4 PISA content. Data collection was done by giving 4 PISA questions on the formulate categories for each content and interview. Data were analyzed based on student error indicators in the formulating process. The results showed, in the context of change and relationships, students experienced an error in understanding the problem that was misinterpreting the question, transforming the problem that was wrong in writing the completion procedure, and the process skills were wrong in the calculation process. In the content of space and form, students experience errors in understanding questions, namely incomplete, incomplete mention of information to solve problems and process skills, which is wrong in choosing formulas. In the content of numbers, students experience errors in understanding questions that are misinterpreting information on problems, transforming questions that are wrong in changing sentences in the questions into mathematical form, and process skills that are wrong in the calculation process. In the uncertainty content and data, students experience errors in reading questions that are wrong in reading important words in the problem, 
transforming questions that are incomplete in writing the completion procedures, and process skills that are wrong in choosing the formula that will be used to solve problems.

Keywords: error analysis, formulating, PISA questions.

\section{PENDAHULUAN}

Pemerintah Indonesia telah mengupayakan untuk memperbaiki pendidikan di Indonesia dengan menerapkan Kurikulum 2013 yang merupakan revisi dari kurikulum sebelumnya. Kompetensi mata pelajaran matematika untuk jenjang sekolah menengah yang dimuat dalam Lampiran Permendikbud Nomor 21 tahun 2016 yaitu menunjukkan sikap logis, kritis, analitis, cermat dan teliti, bertanggung jawab, responsif, dan tidak mudah menyerah dalam memecahkan masalah. Hal tersebut juga sesuai dengan tujuan PISA yaitu memastikan apakah siswa dapat menerapkan pengetahuan dan memeriksa seberapa baik siswa dapat memperkirakan dari apa yang telah mereka pelajari dan dapat menerapkan pengetahuan itu dalam kehidupan sehari-hari (OECD,2019). Oleh karena itu cara untuk mengetahui apakah kompetensi matematika di Indonesia tercapai adalah mengikuti Programme for International Student Assesment (PISA).

PISA (Programme International Student Assessment) merupakan sebuah studi yang diselenggarakan oleh Organization for Economic Cooperation and Development (OECD). PISA diadakan setiap 3 tahun sekali dan diikuti oleh siswa yang berusia 15 tahun. Soalsoal PISA disajikan dalam bentuk soal kontekstual yang diambil dari fenomena atau kegiatan dalam kehidupan sehari-hari. Dalam OECD (2019), kategori konten pada PISA dibagi menjadi 4 yaitu 1) change and relationship (perubahan dan hubungan), 2) space and shape (ruang dan bentuk), 3) quantity (bilangan), dan 4) uncertainty and data (ketidakpastian dan data). Konten dalam PISA ini sesuai dengan konten yang ada pada Standar Isi mata pelajaran matematika untuk jenjang sekolah menengah yang dimuat dalam Lampiran Permendikbud Nomor 21 tahun 2016 yang meliputi bilangan, geometri dan pengukuran, aljabar, peluang, dan statistika.

Indonesia telah mengikuti studi PISA sejak tahun 2000. Namun, hasil yang diperoleh menunjukkan kemampuan literasi matematika siswa Indonesia masih rendah. Capaian hasil literasi matematika siswa Indonesia disajikan dalam tabel berikut.

Tabel 1. Capaian Hasil Literasi Matematika Siswa Indonesia dalam Studi PISA.

\begin{tabular}{|c|c|c|c|}
\hline $\begin{array}{c}\text { Tahun Pe- } \\
\text { laksanaan }\end{array}$ & $\begin{array}{c}\text { Banyak } \\
\text { Peserta }\end{array}$ & $\begin{array}{c}\text { Peringkat } \\
\text { Indonesia }\end{array}$ & $\begin{array}{c}\text { Skor } \\
\text { Indonesia }\end{array}$ \\
\hline \hline 2000 & 41 & 39 & 367 \\
\hline 2003 & 40 & 38 & 360 \\
\hline 2006 & 57 & 50 & 391 \\
\hline 2009 & 65 & 60 & 371 \\
\hline 2012 & 65 & 64 & 375 \\
\hline
\end{tabular}

Lanjutan Tabel 1.

\begin{tabular}{|c|c|c|c|}
\hline $\begin{array}{c}\text { Tahun Pe- } \\
\text { laksanaan }\end{array}$ & $\begin{array}{c}\text { Banyak } \\
\text { Peserta }\end{array}$ & $\begin{array}{c}\text { Peringkat } \\
\text { Indonesia }\end{array}$ & $\begin{array}{c}\text { Skor } \\
\text { Indonesia }\end{array}$ \\
\hline \hline 2015 & 70 & 62 & 386 \\
\hline 2018 & 79 & 72 & 379 \\
\hline
\end{tabular}

(Sumber: OECD 2000; OECD 2003; OECD 2006; OECD 2009; OECD 2012; OECD 2015; OECD 2019).

Hasil penelitian Edo, dkk (2013) menyatakan siswa Indonesia mengalami kesulitan pada proses merumuskan masalah kontekstual ke dalam model matematika. Dalam PISA soal dengan tipe merumuskan masalah termasuk dalam kategori proses formulate (memformulasi). Proses formulate menunjukkan seberapa efektif siswa mampu mengenali dan mengidentifikasi soal matematika dan kemudian menyediakan struktur matematika yang diperlukan untuk merumuskan soal ke dalam bentuk matematika (OECD, 2019). Oleh karena itu, terdapat suatu tahapan penyelesaian agar siswa dapat mengidentifikasi soal matematika dan membuat struktur matematika. Siswa harus membaca soal tersebut agar dapat mengidentifikasi informasi yang terdapat pada soal, sehingga siswa dapat membuat model matematika untuk menemukan solusi dari soal tersebut. Jadi, dapat disimpulkan proses formulate meliputi, (1) memahami soal; (2) mengidentifikasi informasi; (3) membuat model matematika; (4) menyelesaikan model matematika; (5) membuat kesimpulan.

Hasil penelitian Oktaviana (2019) menyatakan sebanyak 80 siswa, yang dapat menyelesaikan soal PISA kategori formulate dengan tepat pada konten perubahan dan hubungan, ruang dan bentuk, bilangan, serta ketidakpastian dan data berturut-turut, 33,75\% (27 siswa), $17,5 \%$ (14 siswa), 31,25\% (25 siswa), dan 18,75\% (15 siswa). Hal tersebut menunjukkan siswa masih banyak melakukan kesalahan dalam menyelesaikan soal PISA, sehingga hasil pekerjaan siswa perlu dianalisis sehingga dapat diketahui kesalahan apa yang dilakukan oleh siswa ketika menyelesaikan soal PISA. Dengan demikian, informasi terkait kesalahan-kesalahan yang dilakukan oleh siswa dapat digunakan guru sebagai acuan dalam menentukan rancangan pembelajaran yang sesuai untuk meminimalisir terjadinya kesalahan yang serupa.

Metode untuk menganalisis kesalahan siswa dalam penelitian ini menggunakan prosedur Newman atau Newman's Error Analysis (NEA). Newman (dalam Clements, 1980) menyebutkan hirarki dalam menyelesaikan soal diantaranya, (1) membaca soal; (2) emahami apa yang dibaca; (3) mentransformasi apa yang didapat; (4) menerapkan keterampilan untuk menyelesaikan soal; dan (5) Membuat kesimpulan dari 
jawaban yang ada. Hirarki tersebut memiliki kesamaan dengan 5 proses formulate. Oleh karena itu, NEA sesuai untuk menganalisis kesalahan siswa pada penelitian ini.

Dalam penelitian ini digunakan soal-soal PISA kategori formulate di setiap domain konten PISA. Soal yang digunakan juga memakai konten yang sesuai dengan SI mata pelajaran matematika yang termuat dalam Lampiran Permendikbud Nomor 21 tahun 2016.

Berdasarkan latar belakang yang telah diuraikan, dirumuskan pertanyaan penelitian, (1) bagaimanakah kesalahan siswa dalam menyelesaikan soal PISA kategori formulate pada konten perubahan dan hubungan, (2) bagaimanakah kesalahan siswa dalam menyelesaikan soal PISA kategori formulate pada konten ruang dan bentuk, (3) bagaimanakah kesalahan siswa dalam menyelesaikan soal PISA kategori formulate pada konten bilangan, dan (4) bagaimanakah kesalahan siswa dalam menyelesaikan soal PISA kategori formulate pada konten ketidakpastian dan data.

\section{METODE}

Penelitian ini merupakan penelitian deskriptif kualitiatif yang bertujuan untuk mendeskripsikan kesalahan siswa dalam menyelesaikan soal PISA kategori formulate. Rancangan penelitian yang dilakukan pada penelitian ini yaitu, (1) membuat instrumen penelitian, (2) mengambil data, (3) meganalisis data, dan (4) membuat laporan.

Sumber data pada penelitian ini yaitu siswa kelas VIII di SMP Negeri 2 Krian yang berjumlah 310 siswa. Untuk penentuan subjek, 310 siswa diberikan tes soal PISA kategori formulate yang terdiri dari 4 konten. Selanjutnya, dipilih satu subjek pada tiap konten PISA. Subjek yang dipilih berdasarkan beberapa kriteria yaitu siswa memiliki kelengkapan jawaban, berindikasi memahami soal namun salah dalam memodelkan soal, variasi kesalahan pada jawaban, dan memiliki kelancaran dan keterbukaan dalam berkomunikasi.

Teknik pengumpulan data pada penelitian ini menggunakan metode wawancara berbasis tugas. Tugas yang diberikan berupa soal tes PISA kategori formulate yang terdiri dari empat konten. Tujuan diberikan tes soal PISA yaitu untuk mengetahui bagaimana jawaban siswa dalam menyelesaikan soal. Soal tes PISA pada penelitian ini tersedia pada lampiran. Wawancara dilakukan setelah empat subjek mengerjakan tes soal PISA kategori formulate. Wawancara dilakukan bertujuan untuk mengungkap apa yang tidak terlihat secara tertulis pada lembar jawaban siswa dan untuk mengetahui alasan dari jawaban yang telah ditulis siswa.

Untuk menganalisis data yang telah diperoleh, peneliti menggunakan indikator kesalahan proses formulate. Berikut disajikan indikator kesalahan proses formulate.
Tabel 2. Indikator kesalahan proses formulate

\begin{tabular}{|c|c|c|c|}
\hline No. & $\begin{array}{c}\text { Proses } \\
\text { Formulate }\end{array}$ & Kesalahan & Indikator \\
\hline \multirow[b]{2}{*}{1.} & \multirow[b]{2}{*}{$\begin{array}{l}\text { Memahami } \\
\text { soal }\end{array}$} & \multirow{2}{*}{$\begin{array}{l}\text { Kesalahan } \\
\text { membaca } \\
\text { soal }\end{array}$} & $\begin{array}{l}\text { Salah membaca } \\
\text { informasi. }\end{array}$ \\
\hline & & & $\begin{array}{l}\text { Salah dalam membaca } \\
\text { kata penting pada per- } \\
\text { tanyaan. }\end{array}$ \\
\hline \multirow{3}{*}{2.} & \multirow{3}{*}{$\begin{array}{l}\text { Meng- } \\
\text { identifikasi } \\
\text { informasi }\end{array}$} & \multirow{3}{*}{$\begin{array}{l}\text { Kesalahan } \\
\text { memahami } \\
\text { soal }\end{array}$} & $\begin{array}{l}\text { Salah menafsirkan } \\
\text { informasi pada soal. }\end{array}$ \\
\hline & & & $\begin{array}{l}\text { Salah menafsirkan per- } \\
\text { tanyaan pada soal. }\end{array}$ \\
\hline & & & $\begin{array}{l}\text { Salah atau tidak } \\
\text { lengkap menyebutkan } \\
\text { informasi untuk me- } \\
\text { nyelesaikan soal. }\end{array}$ \\
\hline \multirow[t]{2}{*}{3.} & \multirow{2}{*}{$\begin{array}{c}\text { Membuat } \\
\text { model } \\
\text { matematika }\end{array}$} & \multirow{2}{*}{$\begin{array}{l}\text { Kesalahan } \\
\text { mentransfor- } \\
\text { masi soal }\end{array}$} & $\begin{array}{l}\text { Salah dalam mengubah } \\
\text { kalimat yang ada pada } \\
\text { soal menjadi bentuk } \\
\text { matematis. }\end{array}$ \\
\hline & & & $\begin{array}{lrr}\text { Salah } & \text { atau tidak } \\
\text { lengkap } & \text { menuliskan } \\
\text { prosedur } & \text { penyelesaian. }\end{array}$ \\
\hline \multirow[t]{2}{*}{4.} & \multirow[t]{2}{*}{$\begin{array}{l}\text { Menyelesai- } \\
\text { kan model } \\
\text { matematika }\end{array}$} & \multirow{2}{*}{$\begin{array}{l}\text { Kesalahan } \\
\text { keterampil- } \\
\text { an proses }\end{array}$} & $\begin{array}{l}\text { Salah dalam memilih } \\
\text { rumus yang digunakan } \\
\text { untuk menyelesaikan } \\
\text { soal. }\end{array}$ \\
\hline & & & $\begin{array}{l}\text { Salah dalam proses } \\
\text { perhitungan. }\end{array}$ \\
\hline \multirow{2}{*}{5.} & \multirow{2}{*}{$\begin{array}{l}\text { Membuat } \\
\text { kesimpulan }\end{array}$} & \multirow{2}{*}{$\begin{array}{l}\text { Kesalahan } \\
\text { menuliskan } \\
\text { hasil akhir }\end{array}$} & $\begin{array}{l}\text { Salah menuliskan hasil } \\
\text { akhir. }\end{array}$ \\
\hline & & & $\begin{array}{l}\text { Salah dalam meng- } \\
\text { gunakan notasi }\end{array}$ \\
\hline
\end{tabular}

\section{HASIL DAN PEMBAHASAN}

Berikut disajikan hasil tes soal PISA kategori formulate pada setiap konten dari 310 siswa.

Tabel 3. Hasil Tes Soal PISA

\begin{tabular}{|l|c|c|c|c|}
\hline \multirow{2}{*}{ Konten } & Kosong & Benar & $\begin{array}{c}\text { Lengkap, } \\
\text { Salah }\end{array}$ & $\begin{array}{c}\text { Tidak } \\
\text { Lengkap }\end{array}$ \\
\cline { 2 - 5 } & 98 & 11 & 91 & 110 \\
\hline \hline $\begin{array}{l}\text { Perubahan dan } \\
\text { hubungan }\end{array}$ & 120 & 53 & 45 & 92 \\
\hline $\begin{array}{l}\text { Ruang dan } \\
\text { Bentuk }\end{array}$ & 157 & 10 & 69 & 74 \\
\hline Bilangan & 165 & $1 / 1$ & 64 & 80 \\
\hline $\begin{array}{l}\text { Ketidakpastian } \\
\text { dan data }\end{array}$ & 110 & \\
\hline
\end{tabular}

Dari hasil tes soal PISA pada 310 siswa dipilih satu siswa pada setiap konten sebagai subjek. Kriteria subjek yang dipilih yaitu berindikasi memahami soal namun salah dalam memodelkan soal tersebut, memiliki kelengkapan jawaban, dan variasi kesalahan pada jawaban. Karena siswa yang memiliki kriteria tersebut lebih dari satu, maka pemilihan subjek juga berdasarkan saran dari guru yaitu siswa yang memiliki kelancaran dan keterbukaan dalam berkomunikasi dan kooperatif dengan peneliti. Berikut rincian siswa yang dipilih sebagai subjek penelitian. 
Tabel 4. Subjek Penelitian

\begin{tabular}{|c|c|c|c|}
\hline No. & Inisial Siswa & Konten & $\begin{array}{c}\text { Kode } \\
\text { Subjek }\end{array}$ \\
\hline \hline 1. & JFI & Perubahan dan hubungan & S01 \\
\hline 2. & AR & Ruang dan bentuk & S02 \\
\hline 3. & KBR & Bilangan & S03 \\
\hline 4. & MNS & Ketidakpastian dan Data & S04 \\
\hline
\end{tabular}

Subjek yang terpilih kemudian diwawancarai untuk mengetahui alasan dari jawaban siswa dan melengkapi informasi penyebab kesalahan siswa. Berikut hasil analisis dan pembahasan mengenai kesalahan siswa.

\section{Konten Perubahan dan Hubungan}

Berikut disajikan hasil pekerjaan S01.

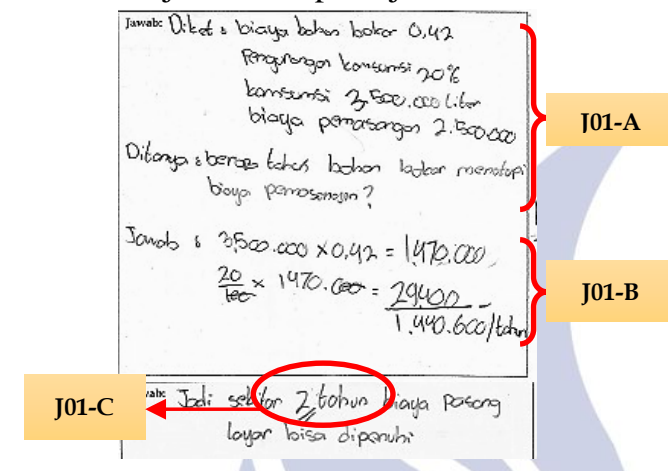

Gambar 1. Hasil Pekerjaan S01

Untuk mengetahui lebih jelas prosedur penyelesaian S01, peneliti melakukan wawancara sebagai berikut.

P-1 : Jelaskan bagaimana cara kamu hingga mendapatkan kesimpulan 2 tahun!

S01-1 : Awalnya mencari biaya diesel per tahun, lalu mencari biaya penghematan setelah dipasang layar, setelah itu mencari biaya konsumsi diesel per tahun setelah pemasangan layar.

P-2 : $3.500 .000 \times 0,42$ untuk mencari apa?

S01-2 : Itu mencari biaya diesel pertahun

P-3 : $\frac{20}{100}$ itu apa?

S01-3 : Dari 20\% penghematan konsumsi diesel, untuk mencari biaya penghematan setelah dipasang layar $\frac{20}{100} \times 1.470 .000=29.400$

P-4 : Lalu mengapa 1.470.000-29.400?

S01-4 : Jadi 1.470.000 kan biaya diesel per tahun sebelum dipasang layar dan 29.400 itu biaya penghematannya. 1.470.000-29.400 untuk mengetahui biaya diesel per tahun setelah dipasang layar.

P-5 : Mengapa mencari biaya diesel setelah dipasang layar?

S01-5 : Kan dicari penghematan untuk menutupi biaya pemasangan

P-6 : Apa hubungan mencari penghematan untuk biaya pemasangan dengan mencari biaya setelah pemasangan?

S01-6 : Di soal kan diketahui kalau setelah dipasang layar dapat menghemat penggunaan diesel. Jadi mencari biaya diesel setelah dipasang layar.
P-7 : Setelah mengetahui biaya diesel per tahun setelah dipasang layar apa yang dilakukan? Mengapa tiba-tiba ada kesimpulan 2 tahun?

S01-7 : Ya dari 1.440 .600 ke 2.500.000 itu butuh berapa tahun? Nah itu kan kurang lebih 2 tahun, kalau 1 tahun kan masih kurang nah kalau 2 tahun kan baru bisa menutupi.

Berdasarkan hasil pekerjaan S01 pada Gambar 1 dan wawancara, diperoleh informasi kesalahan siswa yaitu sebagai berikut.

a. Mengidentifikasi informasi

Hasil wawancara menunjukkan, S01 salah dalam menafsirkan pertanyaan pada soal (S01-6). Kesalahan tersebut juga ditunjukkan pada Gambar 1, S01 menghitung biaya bahan bakar setelah dipasang layar kemudian mencari waktu yang dibutuhkan dari biaya bahan bakar setelah dipasang layar untuk menutupi biaya pemasangan (J01-B, J01-C). Sehingga pada proses mengidentifikasi informasi, S01 mengalami kesalahan memahami soal yaitu salah menafsirkan pertanyaan pada soal.

b. Membuat model matematika

Hasil wawancara menunjukkan, S01 mengalami kesalahan pada bagian mencari konsumsi biaya diesel setelah pemasangan layar (S01-1). Seharusnya hal tersebut tidak perlu dilakukan karena yang ditanya pada soal adalah biaya penghematan bahan bakar yang kemudian akan dibagi dengan biaya pemasangan untuk mencari berapa tahun biaya peghematan dapat menutupi biaya pemasangan layar. Sehingga pada proses membuat model matematika, S01 mengalami kesalahan mentransformasi soal yaitu salah dalam menuliskan prosedur penyelesaian. Hal tersebut disebabkan karena S01 salah dalam menafsirkan pertanyaan.

c. Menyelesaikan model matematika

S01 mengalami kesalahan saat menyelesaikan model matematika yaitu menghitung biaya penghematan setelah dipasang layar. S01 mengalami kesalahan menghitung pada perkalian pecahan (J01-B, S01-3). Sehingga pada proses menyelesaikan model matematika, S01 mengalami kesalahan keterampilan proses yaitu salah dalam proses perhitungan. Hal tersebut disebabkan karena S01 kurang teliti dalam proses menghitung.

Dapat disimpulkan kesalahan yang dialami S01 pada proses formulate ialah: (1) kesalahan memahami soal yaitu salah menafsirkan pertanyaan, (2) kesalahan mentransformasi soal yaitu salah dalam menuliskan prosedur penyelesaian, dan (3) kesalahan keterampilan proses yaitu salah dalam proses perhitungan. 


\section{Konten Ruang dan Bentuk}

Berikut disajikan hasil pekerjaan S02.

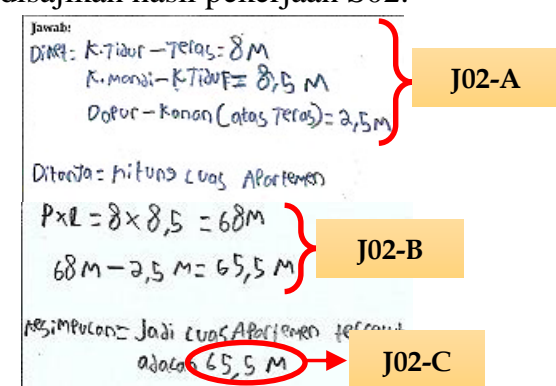

Gambar 2. Hasil Pekerjaan S02

Untuk mengetahui lebih jelas prosedur penyelesaian S02, peneliti melakukan wawancara sebagai berikut.

P-1 : Bagian mana saja yang kamu ukur?

S02-1 : Kamar tidur-teras, kamar mandi-kamar tidur, sama ini (bagian menonjol teras)

P-2 : Hanya tiga sisi yang kamu ukur? Mengapa?

S02-2 : Iya hanya tiga, karena yang dibutuhkan untuk menghitung luas hanya tiga sisi

P-3 : Kan pada soal untuk mengukur luas diperlukan 4 kali mengukur panjang?

S02-3 : Iya, tapi saya menghitung luas hanya menggunakan tiga sisi

P-4 : Jelaskan bagaimana kamu menghitung luasnya?

S02-4 : Bagian apartemen yang kosong ini saya tambahi jadinya apartemennya berbentuk persegipanjang, lalu saya menghitung luas persegipanjang. Lalu ini kan ada sisi yang kosong, jadi luas persegipanjang saya kurangi dengan sisi yang kosong ini

P-5 : $8 \times 8,5$ ini untuk menghitung apa?

S02-5 : Itu menghitung luas apartemen jika tidak ada bagian yang kosong.

P-6 : Lalu hasilnya mengapa dikurangi 2,5?

S02-6 : Kan itu apartemennya tidak berbentuk persegipanjang, ada bagian yang kosong jadi luasnya saya kurangi dengan 2,5

P-7 : Mengapa memilih 2,5

S02-7 : Karena panjang sisi yang kosong ukurannya 2,5 yang bagian atas teras itu, jadi saya kurangi 2,5

P-8 : Kalau misal satuan panjang meter, berarti satua luasnya apa?

S02-8 : Meter persegi

Berdasarkan hasil pekerjaan S02 pada Gambar 2 dan wawancara, diperoleh informasi kesalahan siswa pada proses formulate yaitu sebagai berikut.

a. Mengidentifikasi informasi

S02 hanya melakukan pengukuran panjang pada

3 sisi apartemen dari 6 sisi apartemen (S02-1, J02-

A). S02 mengukur 3 sisi apartemen dikarenakan untuk menghitung luas apartemen S02 hanya menggunakan 3 sisi (S02-2). Hal tersebut tidak sesuai dengan informasi pada soal yaitu harus mengukur 4 sisi dari apartemen untuk menghitung luas seluruh apartemen. Sehingga pada proses mengidentifikasi informasi, S02 mengalami kesalahan memahami soal yaitu tidak lengkap menyebutkan informasi untuk menyelesaikan soal.

b. Menyelesaikan model matematika

S02 menggunakan rumus luas persegipanjang untuk menghitung luas apartemen (S02-4, J02-B). Akan tetapi S02 melakukan kesalahan pada saat mengurangi luas apartemen penuh dengan bagian kosong. Seharusnya untuk mencari luas apartemen rumus yang digunakan adalah luas persegipanjang apartemen penuh dikurangi dengan luas bagian kosong. Akan tetapi, S02 menghitung luas apartemen yaitu mengurangi luas apartemen dengan panjang sisi bagian kosong (S02-6, J02-B). Sehingga pada proses menyelesaikan model matematika, S02 mengalami kesalahan keterampilan proses yaitu salah dalam memilih rumus yang akan digunakan untuk menyelesaikan soal. Hal tersebut disebabkan karena S02 kurang memahami konsep menghitung luas bangun datar tidak beraturan.

Dapat disimpulkan kesalahan yang dialami S02 pada proses formulate ialah: (1) kesalahan memahami soal yaitu tidak lengkap menyebutkan informasi untuk menyelesaikan soal dan (2) kesalahan keterampilan proses yaitu salah dalam memilih rumus yang akan digunakan untuk menyelesaikan soal.

\section{Konten Bilangan}

Berikut disajikan hasil pekerjaan S03.

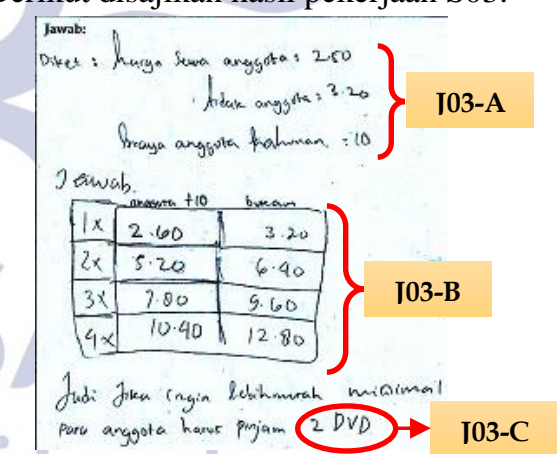

Gambar 3. Hasil Pekerjaan S03

Untuk mengetahui lebih jelas prosedur penyelesaian S03, peneliti melakukan wawancara sebagai berikut.

P-1 : Setelah membaca soal, menurut kamu apa yang ditanyakan?

S03-1 : Berapa minimum DVD yang disewa agar biaya sewa anggota lebih murah dari yang tidak anggota

P-2 : Disini kan kamu membuat tabel, coba jelaskan tabel ini untuk apa?

S03-2 : Untuk mengetahui biaya penyewaan anggota dan bukan anggota. Ini kan biaya sewa satu DVD untuk anggota kan sebenarnya 2.50 , berarti $1 \times 2.50$ terus ditambah 10 jadinya 2.60 terus biaya sewa 
untuk yang tidak anggota 3.50. Terus untuk selanjutnya saya lipatkan

P-3 : Dilipatkan bagaimana maksudnya?

S03-3 : Kan sudah ketemu menyewa 1 DVD yang anggota 2.60 yang tidak anggota 3.50 jadi kalau mau menyewa 2 tinggal dikali 2, gitu seterusnya

P-4 : Kalau tanpa biaya keanggotaan, anggota menyewa 1 DVD harus membayar berapa?

S03-4 : 2.50 zeds

P-5 : Kalau menyewa 2 DVD tanpa biaya keanggotaan jadi harus membayar berapa?

S03-5 : Berarti membayar 5 zeds

P-6 : Kalau anggota menyewa 2 DVD dengan biaya keanggotaan membayar berapa?

S03-6 : 5.20 zeds

P-7 : Mengapa kamu menjawab 5,20 zeds? Berapa biaya keanggotaan yang harus dibayar jika menyewa 2 DVD

S03-7 : Kan kalau 1 DVD biaya keanggotaan 10 zeds, jika 2 DVD jadi 20 zeds

P-8 : Begitu ya, lalu $2.50+10$ itu hasilnya berapa? S03-8 : 2.60 mbak

P-9 : Mengapa tabel yang kamu buat sampai 4?

S03-9 : Sebenarnya masih banyak mbak, cuman biar lebih mempersingkat waktu jadinya saya sampai 4 saja

P-10 : Tapi jawaban yang kamu pilih 2, kenapa?

S03-10: Saya kemarin salah lihat mbak, saya kira tabel sebelah kanan yang anggota

Berdasarkan hasil pekerjaan S03 pada Gambar 3 dan wawancara, diperoleh informasi kesalahan siswa yaitu sebagai berikut

a. Mengidentifikasi informasi

Hasil wawancara menunjukkan, S03 salah dalam menafsirkan informasi yang terdapat pada soal (S03-7). S03 menafsirkan, biaya keanggotaan dibayarkan setiap menyewa DVD. Hal tersebut salah karena biaya keanggotaan dibayarkan setiap satu tahun sekali. Sehingga pada proses mengidentifikasi informasi, S03 mengalami kesalahan memahami soal yaitu salah menafsirkan informasi pada soal.

b. Membuat model matematika

S03 mengalami kesalahan dalam membuat model matematika untuk biaya sewa 2 DVD bagi anggota (S03-3). Dari hasil wawancara S02 menjelaskan model matematika yang dibuat untuk anggota yaitu $1 \times 2.50+10$ untuk satu DVD, dan untuk dua DVD maka hasil menyewa 1 DVD dikalikan 2. Seharusnya model matematika biaya sewa DVD untuk angota yaitu $(\mathrm{n} \times 2.50)+10$, dengan $\mathrm{n}=$ jumlah DVD. Sehingga pada proses membuat model matematika, S03 mengalami kesalahan mentransformasi soal yaitu salah dalam mengubah kalimat yang ada pada soal menjadi bentuk matematis. Hal tersebut disebabkan karena S03 salah menafsirkan informasi.

c. Menyelesaikan model matematika

Ketika menyelesaikan model matematika, hasil wawancara dan Gambar 3 menunjukkan S03 mengalami kesalahan dalam menjumlahkan bilangan desimal (J03-B, S03-8). Sehingga pada proses menyelesaikan model matematika, S03 mengalami kesalahan keterampilan proses yaitu salah dalam proses perhitungan.

dapat disimpulkan kesalahan yang dialami S03 pada proses formulate ialah: (1) kesalahan memahami soal yaitu salah menafsirkan informasi pada soal, (2) kesalahan mentransformasi soal yaitu salah dalam mengubah kalimat yang ada pada soal menjadi bentuk matematis, dan (2) kesalahan keterampilan proses yaitu salah dalam proses perhitungan.

\section{Konten Ketidakpastian dan Data}

Berikut disajikan pekerjaan S04.

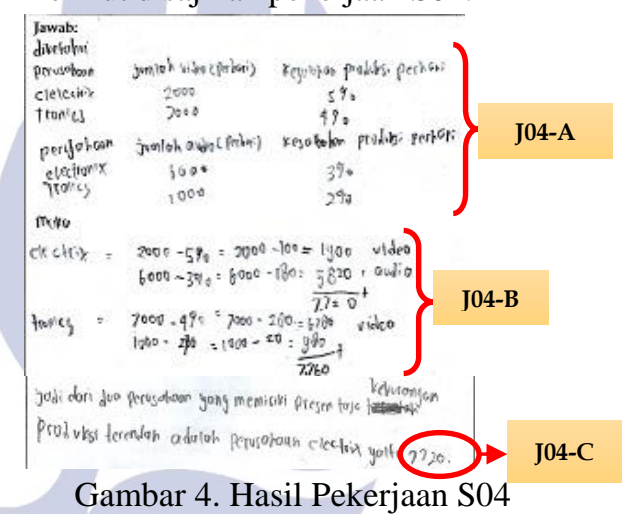

Untuk mengetahui lebih jelas prosedur penyelesaian S04, peneliti melakukan wawancara sebagai berikut.

P-1 : Setelah membaca soal, menurut kamu apa yang ditanyakan pada soal?

S04-1 : Mencari kerusakan yang lebih rendah.

P-2 : Bagaimana cara kamu agar dapat menjawab pertanyaan pada soal?

S04-2 : Dari perusahaan Electrix dulu, menghitung persennya lalu dikurangi 2000

$\mathrm{P}-3$ : Itu untuk menghitung apa?

S04-3 : Persentase kesalahan mbak

P-4 : Lalu, bagaimana menghitungnya?

S04-4 : Kan 2000-5\%=2000-100=1900 itu yang video.

P-5 : 100 itu dari mana?

S04-5 : Ya 5\% dari $2000=100 \mathrm{mbak}$

P-6 : Coba jelaskan mengapa rumus yang kamu pakai untuk mencari kerusakan 2000-5\%

S04-6 : Dari jumlah produksinya 2000 terus persentase kerusakannya $5 \%$ jadi untuk caranya 2000-5\%. Menghitung 5\% dari 2000 lalu 2000 dikurangi dengan hasil persennya itu.

P-7 : Lalu ini 6000-3\% itu apa?

S04-7 : Itu yang audio perusahaan Electrix, terus kesalahan yang audio dan video perusahaan 
Electrix dijumlah. Kesalahan audio dan video perusahaan Tronics juga dijumlah.

P-8 : Setelah itu bagaimana?

S04-8 : Sudah, lalu membuat kesimpulan kekurangan produksi terendah perusahaan Electrix, kan yang Electrix 7720 yang Tronics 7760. Jadi jawabannya Electrix.

P-9 : Sudah? Sampai situ sudah menjawab pertanyaan pada soal?

S04-9 : Sudah, kan yang ditanya kerusakan yang paling rendah.

Berdasarkan hasil pekerjaan S04 pada Gambar 4 dan wawancara, diperoleh informasi kesalahan siswa yaitu sebagai berikut.

a. Mengidentifikasi informasi

Berdasarkan hasil wawancara menunjukkan S04 mengalami kesalahan membaca apa yang ditanyakan pada soal (S04-1, S04-9). S04 menyebutkan bahwa yang ditanyakan pada soal adalah mencari kerusakan produksi yang lebih rendah, seharusnya yang ditanya pada soal adalah persentase kerusakan produksi yang lebih rendah. Sehingga pada proses memahami soal, S04 mengalami kesalahan membaca yaitu salah dalam membaca kata-kata penting dalam pertanyaan.

b. Membuat model matematika

Ketika mencari jumlah kerusakan audio dan video setiap perusahaan, S04 mengalami kesalahan yaitu tidak menghitung persentase jumlah kerusakan produksi pada setiap perusahaan (S04-8). S04 langsung membuat kesimpulan setelah menentukan jumlah kerusakan produksi pada setiap perusahaan tanpa menghitung persentasenya. Sehingga pada proses membuat model matematika, S03 mengalami kesalahan mentransformasi soal yaitu tidak lengkap dalam menuliskan prosedur penyelesaian. Hal tersebut disebabkan karena S04 salah dalam membaca kata-kata penting dalam pertanyaan (S04-1, S04-9).

c. Menyelesaikan model matematika

Hasil wawancara dan Gambar 4, S04 mengalami kesalahan menghitung kerusakan audio dan video pada tiap perusahaan (J04-B). Seharusnya untuk menghitung jumlah kesalahan audio pada perusahaan electrix yaitu $2 \% \times 2000$, begitu juga untuk menghitung kesalahan video. Akan tetapi, S03 menghitung kerusakan dengan cara mengurangi jumlah produksi dengan persentase kerusakan produksi (S04-4, J04-B). Sehingga pada proses menyelesaikan model matematika, S03 mengalami kesalahan keterampilan proses yaitu salah dalam memilih rumus yang akan digunakan untuk menyelesaikan soal. Hal tersebut disebabkan karena S04 kurang memahami konsep materi tentang persentase (S04-6).

dapat disimpulkan kesalahan yang dialami S04 pada proses formulate ialah: (1) kesalahan membaca soal yaitu salah dalam membaca kata-kata penting dalam pertanyaan, (2) kesalahan mentransformasi soal yaitu tidak lengkap dalam menuliskan prosedur penyelesaian, dan (3) kesalahan keterampilan proses yaitu salah dalam memilih rumus

Kesalahan yang dialami siswa saat menyelesaikan soal PISA kategori formulate pada setiap konten sesuai dengan teori Newman (dalam White,2005) yaitu kesalahan siswa dalam menyelesaikan soal dapat diklasifikasikan dalam kesalahan membaca, kesalahan memahami, kesalahan transformasi, kesalahan ketrampilan proses, dan kesalahan menuliskan hasil akhir. Hasil dari penelitian ini relevan dengan penelitian Oktaviana (2019) menunjukkan pada konten perubahan dan hubungan, siswa salah dalam memahami masalah dan salah menyelesaikan soal. Pada konten ruang dan bentuk, siswa salah dalam memahami soal dan salah melakukan pengukuran. Pada konten bilangan, siswa salah dalam memahami soal. Pada konten ketidakpastian dan data sebanyak salah dalam memahami soal dan salam dalam membuat kesimpulan.

\section{PENUTUP}

\section{Simpulan}

Berdasarkan hasil penelitian dan pembahasan, dapat disimpulkan kesalahan siswa dalam menyelesaikan soal PISA kategori formulate pada setiap konten yaitu sebagai berikut. (1) pada konten perubahan dan hubungan, siswa melakukan kesalahan dalam memahami soal yaitu salah menafsirkan pertanyaan soal, mentransformasi soal yaitu salah dalam menuliskan prosedur penyelesaian, dan keterampilan proses yaitu salah dalam proses perhitungan, (2) pada konten ruang dan bentuk, siswa melakukan kesalahan dalam memahami soal yaitu tidak lengkap menyebutkan informasi untuk menyelesaikan soal dan keterampilan proses yaitu salah dalam memilih rumus yang akan digunakan untuk menyelesaikan soal, (3) pada konten bilangan, siswa melakukan kesalahan dalam memahami soal yaitu salah menafsirkan informasi, mentransformasi soal yaitu salah dalam mengubah kalimat yang ada pada soal menjadi bentuk matematis, dan keterampilan proses yaitu salah dalam proses perhitungan, (4) pada konten ketidakpastian dan data, siswa melakukan kesalahan dalam membaca soal yaitu salah dalam membaca kata penting pada soal, mentransformasi yaitu tidak lengkap dalam menuliskan prosedur penyelesaian, dan keterampilan proses yaitu salah dalam memilih rumus yang akan digunakan untuk menyelesaikan soal. 


\section{Saran}

Berdasarkan hasil penelitian, terdapat beberapa saran yang dapat diberikan kepada guru dan peneliti lain yang ingin melakukan penelitian yang relevan yaitu sebagai berikut. (1) karena hasil penelitian menunjukkan siswa paling banyak melakukan kesalahan konsep, maka guru matematika perlu membiasakan siswa menyelesaikan soal yang melibatkan beberapa konsep. Hal tersebut sangat berguna agar siswa tidak melupakan konsep materi yang telah dipelajari, dan (2) karena penelitian ini hanya fokus pada kategori proses formulate di setiap konten, maka perlu dilakukan penelitian lebih lanjut pada kategori proses employ dan interpret agar didapatkan hasil penelitian lebih mendalam mengenai kesalahan siswa dalam menyelesaikan soal PISA.

\section{DAFTAR PUSTAKA}

Clements, M. A. 1980. Analyzing Children's Errors on Written Mathematical Tasks. Educational Studies in Mathematics.

Edo, S. I., Hartono, Y., \& Putri, R. I. 2013. Investigating Secondary School Student's Difficulties in Modelling Problem PISA-Model Level 5 and 6. Journal on Mathematics Education (IndoMS$J M E)$. Vol.4 (1): hal 41-58.

OECD. 2000. PISA 2000 Result in Focus. Paris: OECD Publishing
OECD. 2003. PISA 2000 Result in Focus. Paris: OECD Publishing

OECD. 2006. PISA 2000 Result in Focus. Paris: OECD Publishing

OECD. 2009. PISA 2000 Result in Focus. Paris: OECD Publishing

OECD. 2012. PISA 2012 Results: What Student Know and Can Do. Student Performance in Reading, Mathematics and Science Volume I, III, IV. Paris: OECD Publishing

OECD. 2015. PISA 2015 Assessment and Analytical Framework: Science, Reading, Mathematic and Financial Literacy. Paris: OECD Publishing.

OECD. 2019. PISA 2018 Assessment and Analytical Framework. Paris: OECD Publishing.

Oktaviana, You Ilma. 2019. Kemampuan Siswa Dalam Menyelesaikan Soal PISA Kategori Formulate Pada Siswa Kelas VIII. Surabaya: UNESA.

Permendikbud No. 21 Tahun 2016 Tentang Kompetensi mata pelajaran dan Standar Isi Pendidikan Dasar dan Menengah. Jakarta: Kemendikbud

White, A.L. 2005. Active Mathematics in Classroom: Finding Out Why Children Make Mistakes and Then Doing Something To Help Them. Sydney: University of Western Sydney.

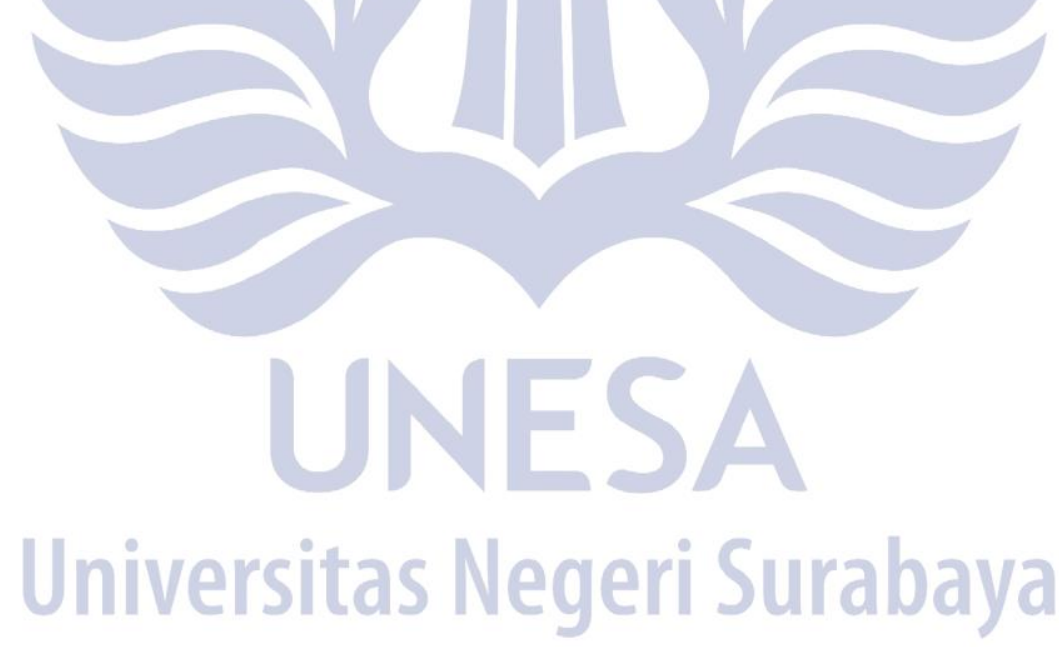




\section{Lampiran Soal Tes PISA}

\section{Konten perubahan dan hubungan (Change and relationship)}

Sembilan puluh lima persen perdagangan dunia disalurkan melalui laut, oleh sekitar 50.000 kapal yang berbahan bakar diesel. Salah satu kapal yang berlayar adalah kapal NewWave. Karena biaya bahan bakar diesel yang tinggi yaitu 0,42 zeds per liter, pemilik kapal NewWave berpikir untuk melengkapi kapal mereka dengan layar layang-layang yang berpotensi mengurangi konsumsi diesel sekitar $20 \%$ secara keseluruhan. Dengan biaya pemasangan layar layanglayang adalah 2.500 .000 zeds.

Nama: NewWave

Jenis: kapal barang

Panjangnya: 117 meter

Lebarnya: 18 meter

Kapasitas muat: 12.000 ton

Kecepatan maksimum: 19 knot

Konsumsi diesel per tahun tanpa layar layang-layang: sekitar 3.500.000 liter

Setelah sekitar berapa tahun penghematan bahan bakar diesel akan menutupi biaya pemasangan layar layanglayang? Berikan perhitungan untuk mendukung jawaban Anda.

\section{Konten ruang dan bentuk (Space and shape)}

Berikut adalah denah apartemen yang akan dibeli oleh orang tua George dari real estate agency.

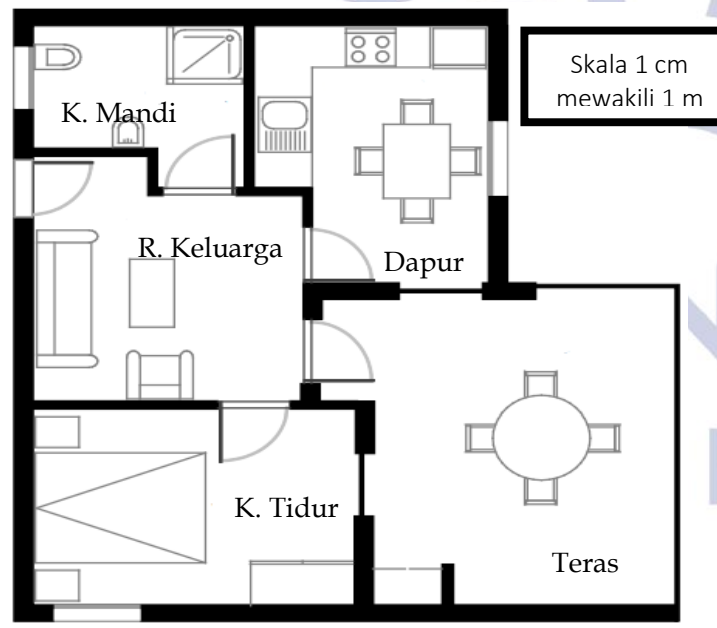

Untuk memperkirakan total luas lantai apartemen (termasuk teras), Anda dapat mengukur ukuran setiap kamar, menghitung luas setiap ruangan kemudian menjumlahkannya. Namun, ada metode yang lebih efisien yaitu Anda hanya perlu melakukan 4 kali mengukur panjang. Tandai empat bagian tersebut kemudian hitung luas apartemen (gunakan penggaris untuk mengukur).

\section{Konten bilangan (Quantity)}

Jenn bekerja di toko penyewaan DVD dan game komputer. Di toko ini biaya keanggotaan tahunan adalah 10 zeds. Biaya sewa DVD untuk anggota lebih murah dari pada yang tidak anggota, seperti yang ditunjukkan pada tabel berikut:

\begin{tabular}{|c|c|}
\hline $\begin{array}{c}\text { Biaya sewa satu DVD } \\
\text { untuk yang tidak } \\
\text { anggota }\end{array}$ & $\begin{array}{c}\text { Biaya sewa satu DVD } \\
\text { untuk anggota }\end{array}$ \\
\hline 3.20 zeds & 2.50 zeds \\
\hline
\end{tabular}

Berapa jumlah minimum DVD yang perlu disewa anggota agar biaya sewanya lebih murah dibanding yang tidak anggota? Tunjukkan pekerjaan Anda.

\section{Konten ketidakpastian dan data (Uncertainty and} data)

Perusahaan Electrix dan perusahaan Tronics adalah perusahaan pembuat dua jenis peralatan elektronik yaitu pemutar video dan audio. Pada akhir produksi harian, alat pemutar tersebut diuji dan apabila ada kerusakan akan diperbaiki.

Berikut disajikan tabel jumlah rata-rata produksi dari setiap jenis yang dibuat per hari, dan persentase ratarata produksi yang salah perhari dari kedua perusahaan tersebut

\begin{tabular}{|c|c|c|}
\hline Perusahaan & $\begin{array}{c}\text { Jumlah rata-rata } \\
\text { video yang } \\
\text { diproduksi (per } \\
\text { hari) }\end{array}$ & $\begin{array}{c}\text { Persentase rata- } \\
\text { rata kesalahan } \\
\text { produksi (per } \\
\text { hari) }\end{array}$ \\
\hline Electrix & 2000 & $5 \%$ \\
\hline Tronics & 7000 & $4 \%$ \\
\hline
\end{tabular}

\begin{tabular}{|c|c|c|}
\hline Perusahaan & $\begin{array}{c}\text { Jumlah rata-rata } \\
\text { audio yang } \\
\text { diproduksi (per } \\
\text { hari) }\end{array}$ & $\begin{array}{c}\text { Persentase rata- } \\
\text { rata kesalahan } \\
\text { produksi (per } \\
\text { hari) }\end{array}$ \\
\hline Electrix & 6000 & $3 \%$ \\
\hline Tronics & 1000 & $2 \%$ \\
\hline \multicolumn{2}{|c|}{ Manakah dari dua perusahaan, yang memiliki } \\
\hline
\end{tabular}

persentase kerusakan produksi lebih rendah? Tampilkan perhitungan yang anda gunakan dari data yang ada pada tabel 